\author{
Asian Journal of Economic Modelling \\ $\operatorname{ISSN}(e): \quad 2312-3656$ \\ $\operatorname{ISSN}(p): \quad 2313-2884$ \\ DOI: $10.18488 /$ journal.8.2014.22.103.114 \\ Vol. 2, No. 2, 103-114 \\ (C) 2014. AESS Publications. All Rights Reserved. \\ URL: wrw.aessweb.com
}

\title{
ARDL BOUNDS TESTING APPROACH TO COINTEGRATION: A RE-EXAMINATION OF AUGMENTED FISHER HYPOTHESIS IN AN OPEN ECONOMY
}

\author{
R. Santos Alimi \\ Economics Department, Adekunle Ajasin University, Akungba-Akoko, \\ Ondo State, Nigeria
}

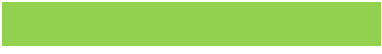

ABSTRACT

\section{Article History \\ Received: $x x x x x x x x x$ \\ Revised: $\mathrm{xxxxxxxxx}$ \\ Accepted: $\operatorname{xxxxxxxxx}$ \\ Published: $\mathrm{xxx \times x \times xxx}$}

\section{Keywords \\ Fisher effects \\ Co-integration \\ Vector error correction model \\ Bound testing \\ Open economy \\ Nigeria.}

\section{JEL Classification:}

This paper investigated the relationship between expected inflation and nominal interest rates in Nigeria and the extent to which the Fisher effect hypothesis holds, for the period 1970-2012. We attempted to advance the field by testing the traditional closed-economy Fisher hypothesis and an augmented Fisher hypothesis by incorporating the foreign interest rate and nominal effective exchange rate variable in the context of a small open developing economy, such as, Nigeria. We applied ARDL bound testing, vector error correction (VECM) and stability of the functions was also tested by CUSUM and CUSUMSQ. We found that full Fisher hypothesis does not hold but there is a Fisher effect in the case of Nigeria over the period under study. In the context of an open economy, the study showed that aside expected inflation, the international variables - foreign interest and nominal effective exchange rates - contain information that predict the nominal interest rate and it also suggested a feed-back mechanism between nominal interest rate and foreign interest rate. Finally, CUSUM test confirms the long-run relationships between the variables and also shows the stability of the coefficients.

Contribution/ Originality: This study is one of very few studies which have investigated the proposition of Fisher that suggests a possibility that the expected inflation is a driver of inflation and extend the fountain of knowledge by incorporating two international monetary variables foreign interest rate and nominal effective exchange rate and test, in the context of an open economy whether foreign interest rate and nominal effective exchange rate provide information on the direction interest rate aside expected inflation in Nigeria. Existing studies on Fisher Hypothesis did not consider this possibility for Nigeria. The study concluded that apart from expected inflation, the international variables contain information that predicts the nominal interest rate. Hence policy makers should look beyond inflation targeting, in order to reduce interest rate to a level that will promote investment and productivity. 


\section{INTRODUCTION}

Obstfeld and Krugman (2003) defined the Fisher effect as "All else equal, a rise in a country's expected inflation rate will eventually cause an equal rise in the interest rate that deposits of its currency offer: Similarly, a fall in the expected inflation rate will eventually cause a fall in the interest rate" (as cited in (Hofer, 2006)).

Fisher (1930) proposed that there should be a long-run relationship in the adjustment of nominal interest rate corresponding to changes in expected inflation such that the short-term interest rates will be an efficient predictor of future inflation. This hypothesis has been the subject of many empirical researches in most developed countries.

This wealth of literature can be attributed to various factors including the pivotal role that the nominal rate of interest and, perhaps more importantly, the real rate of interest plays in the economy. Real interest rate is an important determinant of saving and investment behaviour of households and businesses, and therefore crucial in the growth and development of an economy (Deutsch Bundesbank Report, 2001). The validity of what has come to be known as the Fisher effect has important implications for monetary policy and needs to be considered by monetary authorities.

A significant amount of research has been conducted in developed countries and emerging economies to prove and establish this hypothesis: among the most recent papers are those by Mishkin (1992), Crowder and Hoffman (1996), Fahmy and Kandil (2003), Junttila (2001), Muscatelli and Spinelli (2000), Esteve et al. (2003), Choudhry (1997), Yuhn (1996), Lardic and Mignon (2003), Dutt and Ghosh (1995), Hawtrey (1997), Koustas and Serletis (1999) and Mishkin and Simon (1995), Garcia (1993), Miyagawa and Morita (2003), Carneiro et al. (2002), Lee et al. (1998), Phylaktis and Blake (1993), Jorgensen and Terra (2003), Atkins and Serletis (2002), Ghazali and Ramlee (2003), Wesso (2000), Laatsch and Klien (2002), Tillmann (2004) and Sheefeni (2013).

But few studies have been conducted in Nigeria to validate this important hypothesis, among which are; Obi et al. (2009), Akinlo (2011), Alimi and Ofonyelu (2013) and Ogbonna (2013).

The empirical evidence on the long-run Fisher effect is mixed (for an excellent and comprehensive survey of recent evidence on long-run monetary neutrality and other long-run neutrality propositions, (see Bullard (1999)).

Moreso, there has been renewed academic interest in the empirical testing of Fisher effect due to inflation-targeting monetary policy in many countries of the world and the advances in the time series techniques for studying non-stationary data with the help of various cointegration techniques and recently developed Auto-regressive Distributed Lag (ARDL).

We found that for developing countries, especially Nigeria, there are sparse empirical studies on the existence of fisher effect and this study aims at providing a more insightful literature on the subject.

Moreover, the double digit rates of inflation and interest have continued to be of intense concern to both government and policy-makers. Thus, we investigate the relationship between expected inflation and nominal interest rates in Nigeria and the extent to which the Fisher effect hypothesis holds in the context of a small open economy using Auto-regressive Distributed Lag (ARDL) bound testing for the period 1970-2012 and make use of annual data.

The paper is structured as follows: the next section describes the data and methodology employed in this study. This is followed by results and interpretation and the final section concludes this study.

\subsection{Model Specification}

Fisher (1930) hypothesized that a percentage increase in the expected rate of inflation would bring about a percentage increase in the nominal interest rates. This assertion is described by the Fisher identity:

$\mathrm{i}_{\mathrm{t}}=\mathrm{r}_{\mathrm{t}}+\pi_{\mathrm{t}} \mathrm{t}_{\mathrm{t}}$ 
where $i_{t}$ represents the nominal interest rate, $r_{t}$ is the ex antereal interest rate, and $\pi_{t} e_{t}$ is the expected inflation rate. Using the rational expectations model to estimate inflation expectations would mean that the difference between actual inflation $\left(\pi_{t}\right)$ and expected inflation $\left(\pi_{t}{ }_{t}\right)$ is captured by an error term $(\varepsilon t)$ :

$\pi_{\mathrm{t}}-\pi_{\mathrm{t}}^{\mathrm{e}}=\varepsilon \mathrm{t}$

This rational expectations model for inflation expectations can beincorporated into the Fisher equation as follows.

$\mathrm{i}_{\mathrm{t}}=\mathrm{r}_{\mathrm{t}}+\pi_{\mathrm{t}}$

Re-arranging equation (2) we give;

$\pi_{\mathrm{t}}=\pi_{\mathrm{t}}^{\mathrm{e}}+\varepsilon_{\mathrm{t}}$

where $\varepsilon_{t}$ is a white noise error term. If we assume that the real interest rate is alsogenerated under a stationary process, where $r_{t}{ }^{e}$ is the ex-ante real interest rate and $v_{t}$ is the stationary component, we obtain:

$r_{t}=r_{t}^{e}+v_{t}$

Next substituting equation (4) and (5) into equation (3):

$\mathrm{i}_{\mathrm{t}}=\mathrm{r}_{\mathrm{t}}^{\mathrm{e}}+\pi_{\mathrm{t}}^{\mathrm{e}}+\mu_{\mathrm{t}}$

The equation (6) is the traditional closed-economy Fisher hypothesis. By incorporating the foreign interest rate and nominal effective exchange rate variables, we obtained an augmented fisher hypothesis in a context of small open developing economy. We thus modify equation (6) and specify it as;

$i_{t}=r_{t}^{e}+\pi_{t}^{e}+f_{t}+\operatorname{exch}_{t}+\mu_{t}$

where $\mu_{t}$ is the sum of the two stationary error terms (i.e $\varepsilon_{t}+v_{t}$ ), $r_{t}^{e}$ is the long run real interest rate, $\pi_{\mathrm{t}} \mathrm{e}$ is the expected rate of inflation, $\mathrm{fi}_{\mathrm{t}}$ is the foreign interest rate and $\mathrm{exch}_{\mathrm{t}}$ is the nominal effective exchange rate.

Thus, we estimate the following model;

$\mathrm{INT}_{\mathrm{t}}=\delta+\varphi_{1} \mathrm{INF}_{\mathrm{t}}+\varphi_{2} \mathrm{FINT}_{\mathrm{t}}+\varphi_{3} \mathrm{EXCH}_{\mathrm{t}}+\mu_{\mathrm{t}}$

INT $=$ nominal interest rate

$\mathrm{INF}=$ expected inflation rate

FINT $=$ foreign interest rate

$\mathrm{EXCH}=$ nominal exchange rate

The strong form Fisher hypothesis is validated if a long-run unit proportional relationship exists between expected inflation and nominal interest rates and $\varphi_{1}=1$, if $\varphi_{1}<1$ this would be consistent with a weak form Fisher hypothesis.

The first challenge facing any empirical Fisherian study is how to derive an inflation expectations proxy. Wooldridge (2003) suggested that the expected inflation this year should take the value of last year's inflation, which is adopted in this study: $\pi_{\mathrm{t}}{ }^{\mathrm{e}}=\pi_{\mathrm{t}-1}$.

\section{DATA AND METHODS}

We employed annual time-series data for the period 1970 to 2012 , with a total of 43 observations for each variable. The data on nominal interest and expected inflation are obtained from Central Bank of Nigeria Statistical Bulletin, Annual Report and Statements of Account for different years. We use treasury bill rate as a proxy for nominal interest variable and last year inflation as proxy for expected inflation.

We use US six month London Interbank Rate obtained from the World Economic Outlook Publication Report as proxy for foreign interest rate. All the variables used are in percentage and linear form. In this empirical investigation, we follow three main steps. First, we examine the stationarity of our variables; nominal interest rate, expected inflation rate, foreign interest rate and nominal effective exchange rate. It is observed that a non-stationary time series has a 
different mean at different points in time, and its variance increases with the sample size (Harris and Sollis (2003). The feature of non- stationary time series is very crucial in the sense that any linear combinations of these time series make spurious regression.

When this happens, t-values of the coefficients are highly significant, coefficient of determination $\left(\mathrm{R}^{2}\right)$ is very close to one and the Durbin Watson (DW) statistic value is very low, which often lead investigators to commit a high frequency of Type 1 errors (Granger and Newbold, 1974). As a result, the results of the estimation of the coefficient became biased. Hence, it is necessary to detect the existence of stationarity or non-stationarity in the series in order to avoid the issue of spurious regression. For this, the unit root tests are conducted using the DickyFuller generalized least square (DF-GLS), and Ng-Perron. If a unit root is detected for more than one variable, we further conduct the test for cointegration to determine whether we should use Error Correction Mechanism (ECM). To analyse long run relationship between inflation and financial development, we did not focus on traditional cointegration approaches such as Engle and Granger (1987) and Johansen and Juselius (1990) cointegration approaches.

This study used recent and advanced approach to test whether long run relationship between the variables exists or not by applying autoregressive distributive lag model (ARDL) bounds testing approach developed by Pesaran et al. (2001) because of its numerous advantages. For example, ARDL approach can be applicable if the variables of interest have ambiguous order of integration i.e. purely $\mathrm{I}(0)$, purely $\mathrm{I}(1)$ or $\mathrm{I}(0) / \mathrm{I}(1)$ which is not acceptable in traditional approaches.

Moreso, according to Haug (2002), ARDL bounds testing approach is more suitable and provides better results for small sample size and the short and long-run parameters are estimated simultaneously. The unrestricted error correction model is used for equation-8 as following:

The ARDL representation of the trade openness and economic growth relationship can be constructed as:

$\Delta \mathrm{INT}_{\mathrm{t}}=\lambda_{0}+\lambda_{1} \mathrm{INT}_{\mathrm{t}-1}+\lambda_{2} \mathrm{INF}_{\mathrm{t}-1}+\lambda_{3} \mathrm{FINT}_{\mathrm{t}-1}+\lambda_{4} \mathrm{EXCH}_{\mathrm{t}-1}+\lambda_{5} \Delta \mathrm{INT}_{\mathrm{t}-\mathrm{i}}+\lambda_{6} \Delta \mathrm{INF}_{\mathrm{t}-\mathrm{i}}+$ $\lambda_{7} \Delta \mathrm{FINT}_{\mathrm{t}-\mathrm{i}}+\lambda_{8} \Delta \mathrm{EXCH}_{\mathrm{t}-\mathrm{i}}+\eta \mathrm{ECM}_{\mathrm{t}-1}+\varepsilon_{\mathrm{t}}$

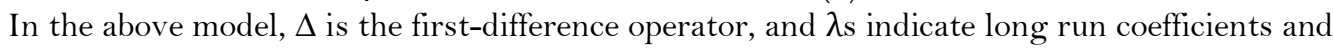
short run coefficients are represented as. The hypothesis of no cointegration deals with $\mathrm{H}_{0}: \lambda_{1}=$ $\lambda_{2}=\lambda_{3}=\lambda_{4}=\lambda_{5}=\lambda_{6}=\lambda_{7}=\lambda_{8}=0$ and $\mathrm{H}_{1}: \lambda_{1} \neq \lambda_{2} \neq \lambda_{3} \neq \lambda_{4} \neq \lambda_{5} \neq \lambda_{6} \neq \lambda_{7} \neq \lambda_{8} \neq 0$ is an alternative hypothesis of cointegration.

Next step is to compare the calculated F-statistic with critical values from Narayan (2005) which were generated for small sample sizes of between 30 and 80 observations. One set assumes that all variables in the model are $I(0)$ and the other set assumes they are all $I(1)$. If the calculated F-statistic exceeds the upper critical bounds value, then the Ho is rejected. If the F-statistic falls within the bounds then the test is inconclusive. Lastly, if the F-statistic falls below the lower critical bounds value, it implies that there is no co-integration.

Granger (1988) demonstrates that causal relations among variables can be examined within the framework of ECM, with cointegrated variables. While the short run dynamics are captured by the individual coefficients of the lagged terms, the error correction term (ECT) contains the information of long run causality. Significance of lagged explanatory variable depicts short run causality while a negative and statistical significant ECT is assumed to signify long run causality. The short-run causality is thus determined from the following ARDL model;

$\Delta \mathrm{INT}_{\mathrm{t}}=\psi_{0}+\psi_{1} \Delta \mathrm{INT}_{\mathrm{t}-\mathrm{i}}+\psi_{2} \Delta \mathrm{INF}_{\mathrm{t}-\mathrm{i}}+\psi_{3} \Delta \mathrm{FINT}_{\mathrm{t}-\mathrm{i}}+\psi_{4} \Delta \mathrm{EXCH}_{\mathrm{t}-\mathrm{i}}+\eta \mathrm{ECM}_{\mathrm{t}-1}+\varepsilon_{\mathrm{t}}$

where, $\Delta$ is the difference operator, ECM representing the error - correction term derived from the long-run cointegrating relation from the above specified ARDL models (10). In equation, $\eta$ should exhibit a negative and significant sign for causality to exist in the long run. Following Narayan and Smyth (2005), we employed Pesaran and Pesaran (1997) to test for parameter stability. Once the error correction models have been estimated, Pesaran and Pesaran (1997) suggest applying the cumulative sum of recursive residuals (CUSUM) and the CUSUM of square (CUSUMSQ) tests to assess the parameter constancy. 


\section{PRESENTATION OF RESULTS AND INTERPRETATION}

\subsection{Unit Root Test}

In order to examine the integrating level of variables, standard tests like DF - GLS, and NgPerron are employed. In most literature, Dickey and Fuller (1979) and Phillips and Perron (1988) tests have been used extensively in order to find out the order of integration, but due to their poor size and power properties, both tests are not reliable for small sample data set (DeJong et al., 1992). These tests seem to over-reject the null hypotheses when it is true and accept the null hypotheses when it is false.

The newly proposed tests such as Dicky-Fuller generalized least square (DF-GLS) detrending test developed by Elliot et al. (1996) and Ng-Perron test following Ng and Perron (2001) seem to solve these problems associated with ADF and PP.

Table-1. DF-GLS Unit Root Test.

\begin{tabular}{l|l|l}
\hline Variables & DF-GLS at level & DF-GLS at first difference \\
\hline INT & -2.422229 & $-7.574083^{\mathrm{a}}$ \\
\hline INF & $-3.253805^{\mathrm{b}}$ & - \\
\hline FINT & $-5.850086^{\mathrm{a}}$ & - \\
\hline EXCH & -1.052663 & $-5.234284^{\mathrm{a}}$ \\
\hline
\end{tabular}

Table-2. Ng-Perron Unit Root Test (at level).

\begin{tabular}{|c|c|c|c|c|}
\hline & MZa & MZt & MSB & MPT \\
\hline INT & -9.18110 & -2.13936 & 0.23302 & 9.93791 \\
\hline INF & -13.5834 & -2.59528 & 0.19106 & 6.77018 \\
\hline FINT & $-48.9309^{a}$ & -4.94528 & 0.10107 & 1.86719 \\
\hline $\mathrm{EXCH}$ & -2.31859 & -1.00693 & 0.43428 & 36.1491 \\
\hline \multicolumn{5}{|c|}{ Ng-Perron at first difference } \\
\hline & MZa & MZt & MSB & MPT \\
\hline INT & $-19.8297^{b}$ & -3.14105 & 0.15840 & 4.64228 \\
\hline INF & $-42.3850^{\mathrm{a}}$ & -4.60331 & 0.10861 & 2.15106 \\
\hline FINT & - & - & - & - \\
\hline $\mathrm{EXCH}$ & $-19.7702^{\mathrm{b}}$ & -3.14090 & 0.15887 & 4.62839 \\
\hline
\end{tabular}

Table-1 shows that under DF-GLS unit root test, expected inflation and foreign interest rate are stationary at levels while nominal interest rate and nominal effective exchange rate become stationary after first difference.

When Ng-Perron unit root was applied, all the series, except foreign interest rate, are nonstationary at level but become stationary after taking their first difference i.e. I(1). Hence, we conclude that these variables are integrated of order one I(1), it therefore necessary to determine whether there is at least one linear combination of the variables that is $1(0)$.

Table-3. Lag Length Selection.

\begin{tabular}{|c|c|c|c|c|}
\hline Lag & FPE & AIC & $\overline{\text { SC }}$ & HQ \\
\hline $\mathrm{O}$ & $1.60 \mathrm{e}+08$ & 30.24132 & 30.41370 & 30.30265 \\
\hline 1 & $3011768 *$ & $26.26341^{*}$ & $27.12529^{*}$ & 26.57006 \\
\hline 2 & 3789921 & 26.46269 & 28.01409 & 27.01467 \\
\hline \multirow[t]{2}{*}{3} & 3602123 & 26.33359 & 28.57449 & 27.13088 \\
\hline & 4374078 & 26.37042 & 29.30084 & 27.41304 \\
\hline
\end{tabular}


Table 3 reports the optimal lag length of one (1) out of a maximum of 4 lag lengths as selected by four different criteria: Final Prediction Error (FPE), Akaike information criteria (AIC), Schwarz Information Criterion and Hannan-Quinn Information Criterion. The results of the ARDL bounds testing approach are also shown in Table 4.

Table-4. ARDL Bounds Test for Cointegration

\begin{tabular}{l|l|l}
\hline Variables & F-Statistics & Cointegration \\
\hline F(INT/ INF, FINT, EXCH) & $4.400628^{*}$ & Cointegration \\
\hline Critical value & Lower Bound & Upper Bound \\
\hline $1 \%$ & 5.018 & 6.610 \\
\hline $5 \%$ & 3.548 & 4.803 \\
\hline $10 \%$ & 2.933 & 4.020 \\
\hline Notes: $* * *$ Statistical significance at $1 \%$ level; ** Statistical significance at $5 \%$ level; $*$ Statistical significance at $10 \%$ level.
\end{tabular}

The lag length $\mathrm{k}=1$ was selected based on the Schwarz criterion (SC). Critical values are obtained from Narayan (2005) case III for 40 observations. The number of regressors is 3 .

Therefore, the empirical findings lead to the conclusion that a long run relationship between nominal interest rate, expected inflation rate, foreign interest rate and nominal effective exchange rate exists. Next step is to examine the marginal impacts of expected inflation, foreign interest rate and nominal effective exchange rate on nominal interest rate in Nigeria.

Table-5. Estimated Long Run Coefficients.

\begin{tabular}{l|l|l}
\hline Variables & Co-efficient & P-value \\
\hline $\mathrm{C}$ & 16.51403 & 0.000 \\
\hline $\mathrm{INF}_{\mathrm{t}}$ & 0.056168 & 0.1759 \\
\hline $\mathrm{FINT}_{\mathrm{t}}$ & -0.579106 & 0.0050 \\
\hline $\mathrm{ECXH}_{\mathrm{t}}$ & -0.48846 & 0.0128 \\
\hline $\mathrm{AR}(1)$ & 0.481945 & 0.0031 \\
\hline $\mathrm{R}^{2}=0.702528 \quad \mathrm{~F}-$ statistic $=21.25493(0.0000)$ &
\end{tabular}

Durbin-Watson stat. $=1.842169$

We estimate the long run equilibrium relationship between the variables in equation (9) and report the estimation results, including the estimated first-order autoregressive coefficient of the error term in Table 5, using OLS. Our empirical evidence reveals that relationship between nominal interest rate and expected inflation is positive but not on one-to-one basis and it is not statistically significant at $10 \%$. Whereas foreign interest rate and exchange rate's estimated longrun coefficients are significant at $1 \%$ and $5 \%$ respectively. The result of long run estimated coefficient shows that a ten percentage increase in expected inflation rate will lead to about 0.6 percentage rises in nominal interest rate while a ten percentage rise in foreign interest rate will bring about a fall in nominal interest rate by 6 percent. Furthermore, a ten percentage increase in nominal effective exchange rate will lead to about 5 percentage fall in nominal interest rate. This shows that both foreign interest rate and nominal exchange rate have deleterious effect on nominal interest rate. The coefficient of determination $\left(\mathrm{R}^{2}\right)$ is 0.782943 . The result shows that about $80 \%$ of variation in nominal interest rate is caused by variations in the explanatory variables. The Durbin-Watson statistics is 0.702528 which shows the absence of serial correlation.

\subsection{The Dynamics of Short-Run Causality}

We estimated equation (10), to determine the nature and direction of short-run dynamics of the selected variables. Thereafter, F-test was employed to test the joint significance of the lagged variables. Table 6 presents the estimated results as above. In the short-run, the nominal interest rate equation suggests that only foreign interest rate and one lagged expected inflation variables have significant impact on nominal interest rate. The ECM term included in the equation is not statistically significant. Moreso, the result of short run dynamics showed that in expected inflation equation, showed no causality between expected inflation and other variables. However, the ECM term included in the equation has the correct sign and is statistically significant at $5 \%$ level. Table 6 also suggested a feed-back mechanism between nominal interest rate and foreign 
interest rate. Finally, exchange rate equations show no evidence of short run relationship with other variables. We conducted next the Wald coefficient tests to investigate and validate whether full Fisher Hypothesis holds for Nigeria or not, and if not, to verify if there is Fisher effect at all. The results of these tests are reported in tables 7 and 8 . The Wald test results shown in table 7 reveal that full (standard) Fisher's hypothesis does not hold in the Nigerian economy. The Wald tests in table 8 show that Fisher effect is strong in the economy and that the other variables are significantly different from zero.

Table-6. Granger Causality Test using VECM.

\begin{tabular}{|c|c|c|c|c|}
\hline Regressors/ & $\triangle$ NOMINT & $\triangle \mathrm{EXPINF}$ & $\triangle$ FORINT & $\triangle \mathrm{NEER}$ \\
\hline Constant & $\begin{array}{l}0.0039 \\
(0.9945)\end{array}$ & $\begin{array}{l}0.7578 \\
(0.7455)\end{array}$ & $\begin{array}{l}-0.1975 \\
(0.5430)\end{array}$ & $\begin{array}{l}0.3915 \\
(0.8923)\end{array}$ \\
\hline$\Delta \mathrm{INT}$ & - & $\begin{array}{l}1.0518 \\
(0.1555)\end{array}$ & $\begin{array}{l}-0.1840^{*} \\
(0.0716)\end{array}$ & $\begin{array}{l}-0.7864 \\
(0.3961)\end{array}$ \\
\hline$\Delta \mathrm{INT}(-1)$ & $\begin{array}{l}-0.1958 \\
(0.2511)\end{array}$ & $\begin{array}{l}0.9490 \\
(0.1722)\end{array}$ & $\begin{array}{l}-0.0289 \\
(0.7685)\end{array}$ & $\begin{array}{l}-0.9065 \\
(0.2952)\end{array}$ \\
\hline$\Delta \mathrm{INF}$ & $\begin{array}{l}0.0628 \\
(0.1555)\end{array}$ & - & $\begin{array}{l}0.0365 \\
(0.1467)\end{array}$ & $\begin{array}{l}0.1842 \\
(0.4162)\end{array}$ \\
\hline$\Delta \mathrm{INF}(-1)$ & $\begin{array}{l}-0.1004^{* * *} \\
(0.0193)\end{array}$ & $\begin{array}{l}-0.0412 \\
(0.8224)\end{array}$ & $\begin{array}{l}-0.0291 \\
(0.2503)\end{array}$ & $\begin{array}{l}-0.1682 \\
(0.4575)\end{array}$ \\
\hline$\Delta \mathrm{FINT}$ & $\begin{array}{l}-0.5660^{*} \\
(0.0716)\end{array}$ & $\begin{array}{l}1.8832 \\
(0.1467)\end{array}$ & - & $\begin{array}{l}-0.9974 \\
(0.5405)\end{array}$ \\
\hline$\Delta \mathrm{FINT}(-1)$ & $\begin{array}{l}0.0083 \\
(0.9790)\end{array}$ & $\begin{array}{l}1.0058 \\
(0.4342)\end{array}$ & $\begin{array}{l}0.2387 \\
(0.1784)\end{array}$ & $\begin{array}{l}0.3721 \\
(0.8160)\end{array}$ \\
\hline $\mathrm{EXCH}$ & $\begin{array}{l}-0.0306 \\
(0.3961)\end{array}$ & $\begin{array}{l}0.1202 \\
(0.4162)\end{array}$ & $\begin{array}{l}-0.0126 \\
(0.5405)\end{array}$ & - \\
\hline$\triangle \mathrm{EXCH}(-1)$ & $\begin{array}{l}0.0270 \\
(0.4411)\end{array}$ & $\begin{array}{l}0.1493 \\
(0.2962)\end{array}$ & $\begin{array}{l}0.0071 \\
(0.7220)\end{array}$ & $\begin{array}{l}0.2662 \\
(0.1284)\end{array}$ \\
\hline ecm $(-1)$ & $\begin{array}{l}0.0311 \\
(0.8819)\end{array}$ & $\begin{array}{l}-1.8731^{* *} \\
(0.0226)\end{array}$ & $\begin{array}{l}0.0082 \\
(0.9453)\end{array}$ & $\begin{array}{l}1.6297 \\
(0.1171)\end{array}$ \\
\hline
\end{tabular}

Table-7. Wald coefficient test for strong Fisher Hypothesis

\begin{tabular}{|c|c|c|c|}
\hline \multicolumn{4}{|c|}{ Estimated equation; $\mathrm{INT}_{\mathrm{t}}=\delta+\varphi_{1} \mathrm{INF}_{\mathrm{t}}+\varphi_{2} \mathrm{FINT}_{\mathrm{t}}+\varphi_{3} \mathrm{EXCH}_{\mathrm{t}}$} \\
\hline \multicolumn{4}{|c|}{ Null Hypothesis; $\varphi_{1}=1$} \\
\hline Test Statistics & Value & Df & Probability \\
\hline t-statistics & -23.19842 & 36 & 0.0000 \\
\hline F- statistics & 538.1665 & $(1,36)$ & 0.0000 \\
\hline $\mathrm{x}^{2}-$ statistics & 538.1665 & 1 & 0.0000 \\
\hline
\end{tabular}

Table-8. Wald coefficient test for the significance of constant and other dependent variable

Estimated equation; INT $\mathrm{IN}_{\mathrm{t}}=\delta+\varphi_{1} \mathrm{INF}_{\mathrm{t}}+\varphi_{2} \mathrm{FINT}_{\mathrm{t}}+\varphi_{3} \mathrm{EXCH}_{\mathrm{t}}$

Null Hypothesis; $\delta=0, \varphi_{1}=0, \varphi_{2}=0, \varphi_{3}=0$,

\begin{tabular}{l|l|l|l}
\hline Test Statistics & Value & Df & Probability \\
\hline F- statistics & 33.22789 & $(4,36)$ & 0.0000 \\
\hline $\mathrm{x}^{2}-$ statistics & 132.9116 & 4 & 0.0000 \\
\hline
\end{tabular}

\subsection{Stability Tests}

Finally, we have examined the stability of the long-run parameters together with the shortrun movements for the equations. For test, we relied on cumulative sum (CUSUM) and cumulative sum squares (CUSUMSQ) tests proposed by Borensztein et al. (1998). This same procedure has been utilized by Pesaran and Pesaran (1997), Mohsen et al. (2002) and Suleiman (2005) to test the stability of the long-run coefficients. The tests applied to the residuals of the ECM model. 
Asian Journal of Economic Modelling, 2014, 2(2): 103-114

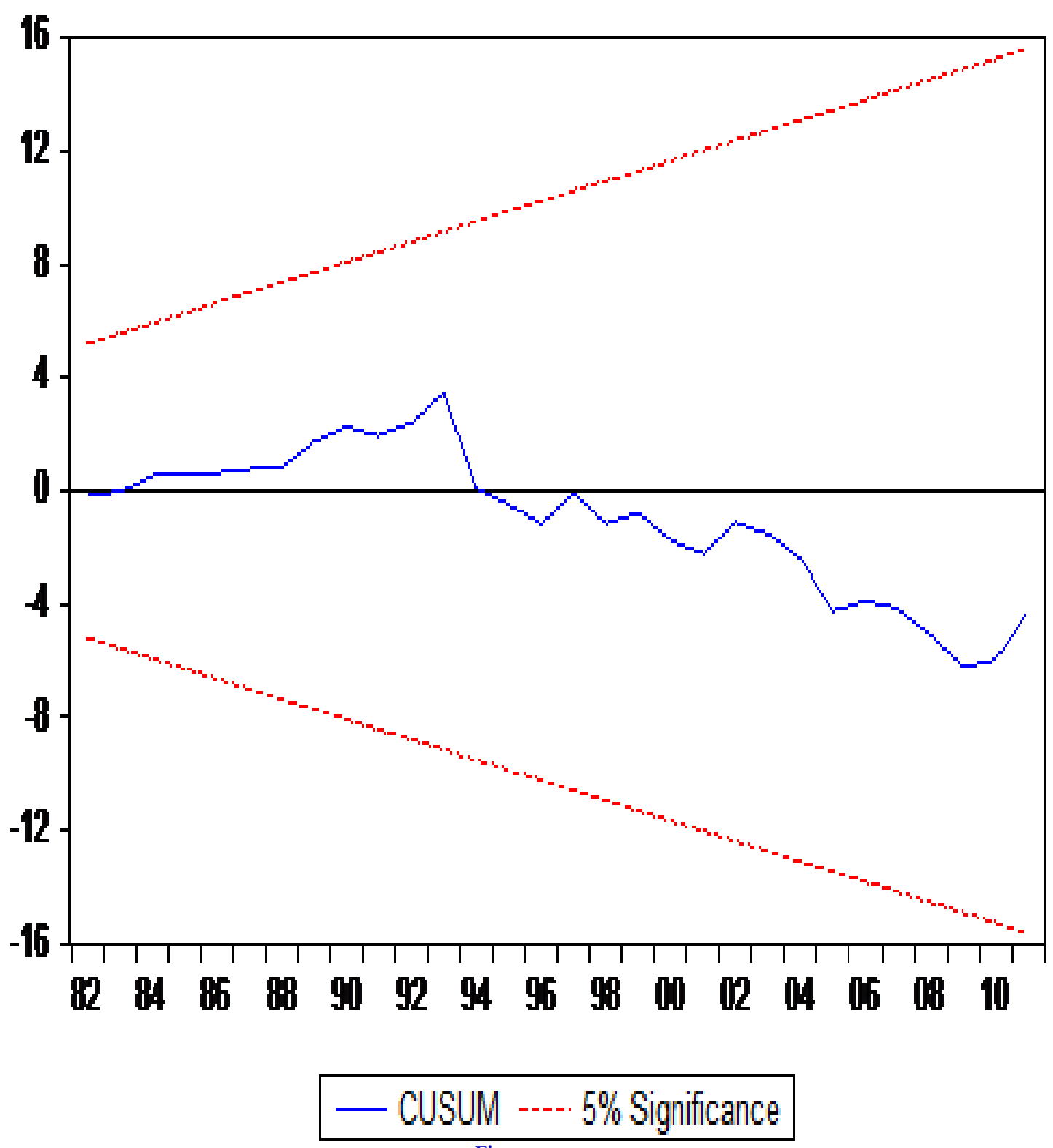

Figure-1. 


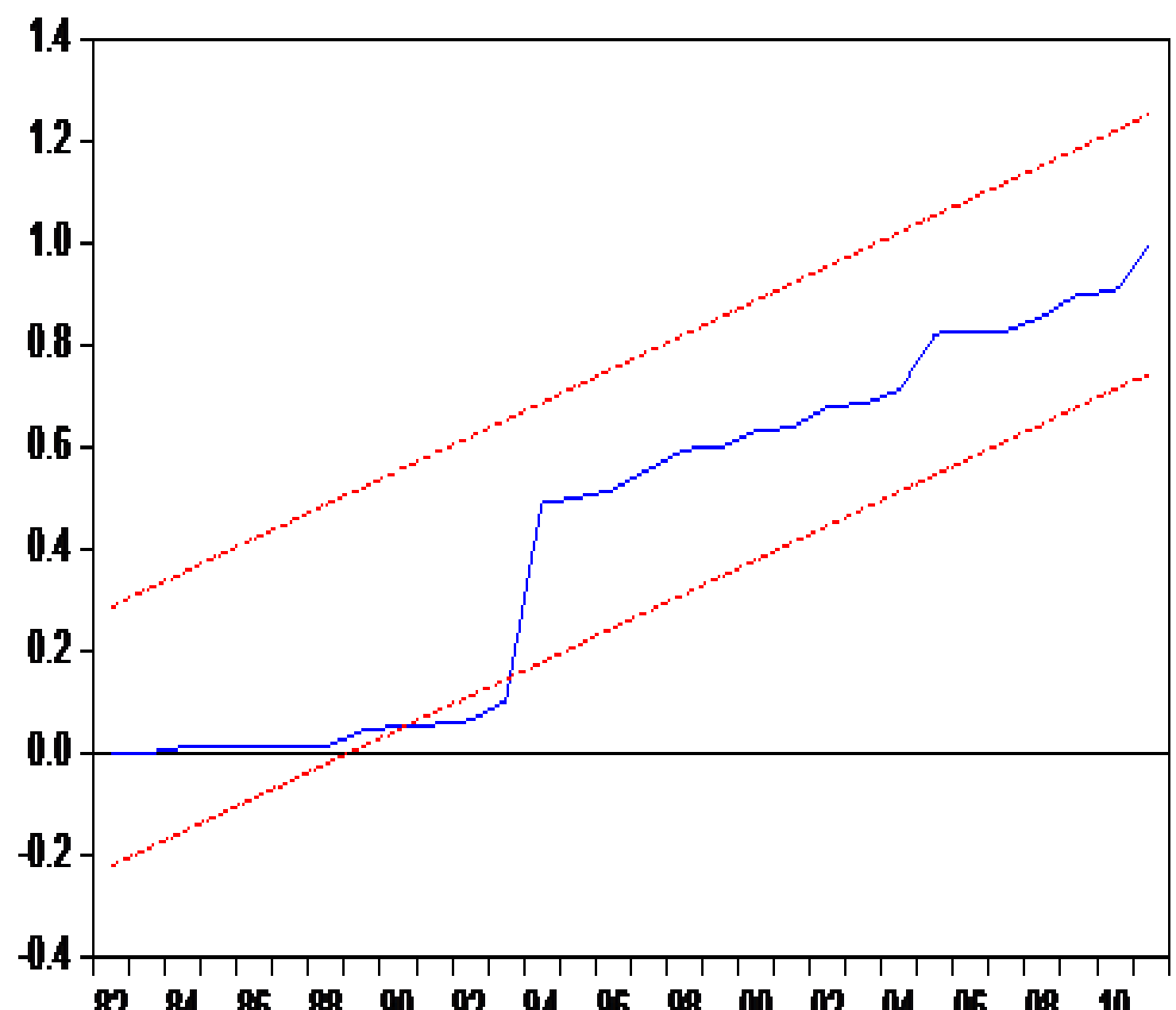

\section{$\begin{array}{lllllllllllllll}82 & 84 & 85 & 89 & 90 & 92 & 94 & 95 & 99 & 00 & 02 & 04 & 05 & 08 & 10\end{array}$}

\section{CUSUM of Squares ---. $5 \%$ Significance \\ Figure-2.}

Figures 1 and 2 plot the CUSUM and CUSUM of squares statistics for Equation (10). It can be seen from Figure 1 that the plot of CUSUM stays within the critical $5 \%$ bounds that confirms the long-run relationships among variables and thus shows the stability of coefficient. However, CUSUMSQ statistics exceed the $5 \%$ critical bounds of parameter stability, thus indicates instability of the coefficient.

\section{SUMMARY AND CONCLUSION}

This paper investigates the relationship between expected inflation and nominal interest rates in Nigeria and the extent to which the Fisher effect hypothesis holds, for the period 19702012. We attempted to advance the field by testing the traditional closed-economy Fisher hypothesis and an augmented Fisher hypothesis by incorporating the foreign interest rate and nominal effective exchange rate variable in the context of a small open developing economy, such as, Nigeria.

We applied ARDL bound testing, vector error correction (VECM) in our analysis and also used CUSUM and CUSUMSQ to test the stability of the model used. The results of the unit root tests indicated the variables under study were I(1) processes and the Error Correction Model was 
consequently employed. The cointegration results show that there is long run relationship between nominal interest rates, expected inflation and the international variables, which implies that all the variables move together in the long run.

With the use of Wald coefficient test, this study tends to suggest that the nominal interest rates and expected inflation move together in the long run but not on one-to-one basis. This indicates that full Fisher hypothesis does not hold but there is a Fisher effect in the case of Nigeria over the period under study. Moreso, the paper revealed that in the closed-economy context, the causality run strictly from expected inflation to nominal interest rates as suggested by the Fisher hypothesis and there is no "reverse causation." This conclusion is consistent with other studies like Obi et al. (2009), Akinlo (2011) and Alimi and Ofonyelu (2013). In the context of an open economy, our result showed that aside expected inflation, the international variables foreign interest and nominal effective exchange rates - contain information that predict the nominal interest rate.

Moreso, there is inverse relationship and feed-back effect between nominal interest rate and the international variables. This finding is at variance with Alimi and Ofonyelu (2013), who used minimum rediscount rate to capture interest rate variable and found no causality between nominal interest rate and foreign interest rate. Finally, we conducted CUSUM and CUSUMSQ tests of which only CUSUM test confirms the long-run relationships between variables and also shows the stability of the coefficients.

The policy implication based on the partial Fisher effect in Nigeria is that more credible policy should anchor a stable inflation expectation over the long-run and the level of actual inflation should become the central target variable of the monetary policy. Moreso, the inverse relationship and feed-back effect between nominal interest rate (treasury bill rate) and foreign interest rate calls for a consideration by policy makers. Since high foreign interest rate will be an incentive for capital flight by an economic agent and low foreign interest rate will encourage capital inflow.

\section{REFERENCES}

Akinlo, A.E., 2011. A re-examination of the fisher hypothesis for Nigeria. Akungba Journal of Economic Thought, 5(1): 5-10.

Alimi, R.S. and C.C. Ofonyelu, 2013. Toda-Yamamoto causality test between money market interest rate and expected inflation: The fisher hypothesis revisited. European Scientific Journal, 9(7): 125-142.

Atkins, F.J. and A. Serletis, 2002. A bounds test of the gibson paradox and the fisher effect: Evidence from low-frequency international data. Discussion Paper 2002-13. Calgary: Department of Economics, University of Calgary.

Borensztein, E., J. De Gregorio and J.-W. Lee, 1998. How does FDI affect economic growth. Journal of International Economics, 45(1): 115-135.

Bullard, J., 1999. Testing long-run monetary neutrality propositions: Lessons from the recent research. Review, Federal Reserve Bank of St. Louis, 81(6): 57-77.

Carneiro, F.G., J.A.C.A. Divino and C.H. Rocha, 2002. Revisiting the fisher hypothesis for the cases Argentina, Brazil and Mexico. Applied Economics Letters, 9(2): 95-98.

Choudhry, A., 1997. Cointegration analysis of the inverted fisher effect: Evidence from Belgium, France and Germany. Applied Economics Letters, 4(4): 257-260.

Crowder, W.J. and D.L. Hoffman, 1996. The long-run relationship between nominal interest rates and inflation: The fisher equation revisited. Journal of Money, Credit, and Banking, 28(1): 102-1 18.

DeJong, D.N., J.C. Nankervis, N.E. Savin and C.H. Whiteman, 1992. Integration versus trend stationarity in time series. Econometrica, 60(2): 423-433.

Deutsch Bundesbank Report, 2001. Real interest rates: Movement and determinants. Monthly Report July. pp: 31-47.

Dickey, D. and W. Fuller, 1979. Distribution of the estimators for autoregressive time series with a unit root. Journal of the American Statistical Association, 74(366): 427-731.

Dutt, S.D. and D. Ghosh, 1995. The fisher hypothesis: Examining the Canadian experience. Applied Economics, 27(11): 1025-1030.

Elliot, G., T.J. Rothenberg and J.H. Stock, 1996. Efficient tests for an autoregressive unit root. Econometrica, 64(4): 813-836.

Engle, R.F. and C.W.J. Granger, 1987. Cointegration and error correction representation: Estimation and testing. Econometrica, 55(2): 251-276. 
Esteve, V., O. Bajo-Rubio and C. Diaz-Roldan, 2003. Testing the fisher effect in the presence of structural change: A case study of the UK, 1961-2001. Documento de trabajo, Serie Economia E2003/22. Sevilla: Fundacion Centro de Estudios Andaluces.

Fahmy, Y.A.F. and M. Kandil, 2003. The fisher effect: New evidence and implications. International Review of Economics \& Finance, 12(4): 45 1-465.

Fisher, I., 1930. The theory of interest. New York: Macmillan.

Garcia, M.G.P., 1993. The fisher effect in a signal extraction framework: The recent Brazilian experience. Journal of Development Economics, 41(1): 71-93.

Ghazali, N.A. and S. Ramlee, 2003. A long memory test of the long-run fisher effect in the G7 countries. Applied Financial Economics, 13(10): 763-769.

Granger, C.W.J., 1988. Causality, cointegration and control. Journal of Economic Dynamics and Control, 12(2-3): 551-559.

Granger, C.W.J. and P. Newbold, 1974. Spurious regression in econometrics. Journal of Econometrics, 2(2): 111-120.

Harris, R. and R. Sollis, 2003. Applied time series modelling and forecasting. United Kingdom: Wiley.

Haug, A.A., 2002. Temporal aggregation and the power of cointegration tests: A monte carlo study. xford Bulletin of Economics and Statistics, 64(4): 399-412.

Hawtrey, K.M., 1997. The fisher effect and Australian interest rates. Applied Financial Economics, 7(4): 337346.

Hofer, M., 2006. EC4090: Quantitative methods the fisher-hypothesis - A simple analysis. Available from http:/www.mario-hofer.biz/exercises/wiwi_qm_fisher.pdf.

Johansen, S. and K. Juselius, 1990. Maximum likelihood estimation and inference on cointegration - with applications to the demand for money. Oxford Bulletin of Economics and Statistics, 52(2): 169-2 10.

Jorgensen, J.J. and P.R.S. Terra, 2003. The fisher hypothesis in a VAR framework: Evidence from advanced and emerging markets.Conference Paper. Helsinki: European Financial Management Association. Annual Meetings, 25-28 June.

Junttila, J., 2001. Testing an augmented fisher hypothesis for a small open economy: The case of Finland. Journal of Macroeconomics, 23(4): 577-599.

Koustas, Z. and A. Serletis, 1999. On the fisher effect. Journal of Monetary Economics, 44(1): 105-130.

Laatsch, F.E. and D.P. Klien, 2002. Nominal rates, real rates and expected inflation U.S treasury inflation: Results from a study of U.S. treasury inflationprotected securities. The Quarterly Review of Economics and Finance, 43(3): 405-417.

Lardic, S. and V. Mignon, 2003. Fractional cointergration between nominal interest rates and inflation: A reexamination of the fisher relationship in the G7 countries. Economic Bulletin, 3(14): 1-10.

Lee, J.L., C. Clark and S.K. Ahn, 1998. Long- and short-run fisher effects: New tests and new results. Applied Economics, 30(1): 113-124.

MacKinnon, J.G., 1996. Numerical distribution functions for unit root and cointe-gration tests. Journal of Applied Econometrics, 11(6): 601-618.

Mishkin, F.S., 1992. Is the fisher effect for real? A reexamination of the relationship between inflation and interest rates. Journal of Monetary Economics, 30(2): 195-215.

Mishkin, F.S. and J. Simon, 1995. An empirical examination of the fisher effect in Australia. Economic Record, 71(214): 217-229.

Miyagawa, S. and Y. Morita, 2003. The fisher effect and the long- run Phillips curve - in the case of Japan, Sweden and Italy.Working Paper in Economics No. 77. Göteborg: Department of Economics, Göteborg University.

Mohsen, Bahmani-Oskooee and R.W. Ng, 2002. Long run demand for money in Hong Kong: An application of the ARDL model. International Journal of Business and Economics, 1(2): 147-155.

Muscatelli, V.A. and F. Spinelli, 2000. Fisher, Barro, and the Italian interest rate 1845-93. Journal of Policy Modeling, 22(2): 149-169.

Narayan, P.K., 2005. The saving and investment Nexus for China: Evidence from cointegration tests. Applied Economics, 37(17): 1979-1990.

Narayan, P.K. and R. Smyth, 2005. The residential demand for electricity in Australia: An application of the bounds testing approach to cointegration. Energy Policy, 33(4): 457-464.

$\mathrm{Ng}$, S. and P. Perron, 2001. Lag lenght selection and the construction of unit root tests with good size and power. Econometrica, 69(6): 1519-1554.

Obi, B., A. Nurudeen and O.G. Wafure, 2009. An empirical investigation of the fisher effect in Nigeria: A cointegration and error correction approach. International Review of Business Research Papers, 5(5): 96-109.

Obstfeld, M. and P.R. Krugman, 2003. International economics: Theory and policy. 6th Edn.: Addison Wesley.

Ogbonna, B.C., 2013. Testing for fisher's hypothesis in Nigeria (1970-2012). Journal of Economics and Sustainable Development, 4(16): 163-171. 
Pesaran, M.H. and B. Pesaran, 1997. Working with microfit 4.0: Interactive econometic analysis. Oxford: Oxford University Press.

Pesaran, M.H., Y. Shin and R.J. Smith, 2001. Bounds testing approaches to the analysis of level relationships. Journal of Applied Econometrics, 16(3): 289-326.

Phillips, P.C.B. and P. Perron, 1988. Testing for a unit root in a time series regression. Biometrika, 75(2): 335-346.

Phylaktis, K. and D. Blake, 1993. The fisher hypothesis: Evidence from three high inflation economies. Weltwirtschaftliches Archiv, 129(3): 591-599.

Sheefeni, J.P., 2013. Testing for the fisher hypothesis in Namibia. Journal of Emerging Issues in Economics, Finance and Banking, 2(1): 571-582.

Suleiman, 2005. The impact of investment and financial intermediation on economic growth: New evidence from Jordan. Abstract Mimeo.

Tillmann, P., 2004. Testing for stationarity and prespecified cointegration under regime-switching: A note on the fisher effect. Working paper. Bonn: The Institute for International Economics, University of Bonn.

Wesso, G.R., 2000. Long-term yield bonds and future inflation in South Africa: A vector error-correction analysis. Quarterly bulletin. Pretoria: South African Reserve Bank. June.

Wooldridge, J.M., 2003. Introductory econometrics: A modern approach. Southwestern.

Yuhn, K., 1996. Is the fisher effect robust? Further evidence. Applied Economics Letters, 3(1): 41-44. 